\title{
Winds vs. tides: factors ruling the recruitment of larval and juvenile fishes into a micro-tidal and shallow choked lagoon (Argentina)
}

\author{
Daniel Osvaldo Bruno • Eduardo Marcelo Acha
}

Received: 28 July 2014 / Accepted: 24 November 2014 / Published online: 30 November 2014

(C) Springer Science+Business Media Dordrecht 2014

\begin{abstract}
Choked lagoons (like Mar Chiquita, Argentina) are influenced by local winds because the inlet channel acts as a dynamic filter which reduce tidal fluctuations. Previous studies showed that the effects of onshore winds appear to prevail over daily-tide cycles (ebb, flood) in the recruitment of young fishes into this micro-tidal and shallow estuary. Therefore, the aim of this study was to evaluate the recruitment success of larval and juvenile fishes from the sea into this choked lagoon related to the conjunction of global (lunar-tide cycle) and local (wind regime) processes. Weekly fish sampling was conducted in Mar Chiquita's inlet channel and its adjacent surf zone from early spring to late summer. For each fish developmental stage (i.e. larval and juvenile), a multiple-hypothesis model approach was adopted by fitting generalized linear models (GLM) with the abundance of fishes as the response variable and possible combinations of seasons, sites, water parameters and the wind effect as explanatory variables. The abundances of fish larvae and juveniles were mainly affected
\end{abstract}

D. O. Bruno $(\bowtie)$

Laboratorio de Ecología, Fisiología y Evolución de Organismos Acuáticos, Centro Austral de Investigaciones

Científicas (CADIC - CONICET), Bernardo Houssay 200,

9410 Ushuaia, Argentina

e-mail: dobruno.ush@gmail.com

E. M. Acha

Instituto de Investigaciones Marinas y Costeras (IIMyC - CONICET - UNMdP) and Instituto Nacional de Investigación y Desarrollo Pesquero (INIDEP),

Paseo Victoria Ocampo $\mathrm{N}^{\circ}$ 1, CC 175, B7602HSA,

Mar del Plata, Argentina by wind regimen and seasonal changes according to the best model selected. Larval and juvenile fishes were more abundant at summer months during strong $\left(>10 \mathrm{~m} \cdot \mathrm{s}^{-1}\right)$ onshore wind episodes. The lunar-tide cycle effect was not relevant for the success of fish recruitment. Despite its seasonal regularity, wind is a much more unpredictable factor than tides, and therefore, it is remarkable to note the implications that have for fishes the recruitment towards an estuarine system depending on such unpredictable force. The importance of the fish nursery role of the coastal area close to the mouth of an estuary with this environmental feature is discussed.

Keywords Fish larvae $\cdot$ Fish juveniles $\cdot$ Estuarine recruitment . Wind effect

\section{Introduction}

Use of estuarine nursery areas is an important phase of the life history of many marine organisms, including fishes (Boehlert and Mundy 1988). As the most common nekton life history cycle of fishes inhabiting estuaries involves offshore spawning (Day et al. 1989), the transport to an estuarine inlet and the subsequent upestuarine movement are crucial for successful completion of the life cycle of several species (Islam et al. 2007). Therefore, studies regarding on the mechanisms of young fishes ingress and retention in nursery areas have caught much attention (e.g. Jager 1999; Epifanio and Garvine 2001; Islam et al. 2007; Primo et al. 2012). 
Aggregations of estuarine associated young fishes in the inshore zone have been related to a number of physical and environmental factors. Winds, tides, river runoff and longshore currents are the main forces involved in larvae and juveniles migrations (Boehlert and Mundy 1988). Also, tidal phase-related factors such as salinity, temperature, chemical substances, current velocity and hydrostatic pressure have been reported to be important to ichthyoplankton distribution (e.g. Primo et al. 2012). Particularly in the case of juveniles, the lunar-tide cycle (spring, neap) can have a strong impact on species distribution because it determines the temporal and spatial availability of coastal habitats like estuaries, saltmarshes and coastal lagoons (Hampel et al. 2003). At neap tide, less area will be flooded, while at spring tide, total inundation time will be longer (Hampel et al. 2003).

Mar Chiquita coastal lagoon $\left(37^{\circ} 32^{\prime} \mathrm{S}, 57^{\circ} 19^{\prime} \mathrm{W}\right)$ is located in the southeast of the Buenos Aires Province (Argentina), which is a micro-tidal area (average tidal amplitude: $0.80 \mathrm{~m}$ ) characterized by semi-diurnal tides (two flood and two ebb tides per day) with different tidal amplitudes between two consecutives floods (Reta et al. 2001; Martos et al. 2004). Despite the micro-tidal regime, tidal amplitude in the coastal area may reach almost $1.60 \mathrm{~m}$ during extraordinary spring tides and almost $2.50 \mathrm{~m}$ during southeasterly storms (Martos et al. 2004). Mar Chiquita is connected to the sea by a $6 \mathrm{~km}$ in length, $200 \mathrm{~m}$ in width and $1.5-3 \mathrm{~m}$ in depth channel. Tidal influence is only perceived $5 \mathrm{~km}$ upstream along this channel and saltwater intrusion varies according to tides and winds (Reta et al. 2001).

Unlike most estuaries, choked lagoons (like Mar Chiquita) are influenced by local winds because the inlet channel acts as a dynamic filter, which significantly reduce tidal fluctuations or tidal currents (Kjerfve and Magill 1989; Kjerfve 1994). Moreover, Reta et al. (2001) argued that strong $\left(>10 \mathrm{~m} \cdot \mathrm{s}^{-1}\right)$ offshore winds $(\mathrm{N}, \mathrm{NW})$ enhance the discharge of this lagoon even during flood, while strong onshore winds (SW, S, SE, E) enhance saltwater intrusion into the lagoon.

It has been stated that the recruitment of fishes into this choked lagoon is related to wind direction during both, larval (Bruno et al. 2014) and juvenile (Bruno 2014) stages. The effects of onshore winds appear to prevail over daily-tide cycles (ebb, flood) in the recruitment of young fishes into this lagoon. Hence, it has been proposed that in this scenario, recruitment models for fish larvae based on tidal cycles (Weinstein et al. 1980;
Boehlert and Mundy 1988; Forward et al. 1999) could not to be suitable, and that juvenile stages which have a more developed swimming activity take advantage of wind-mediated water circulation in order to increase the surplus power (energy per unit time; sensu Miller et al. 1985) (Bruno 2014). Such a proposal, however, has been performed considering only the daily-tide cycle. The broader lunar-tidal scale (i.e. neap/spring cycles) has not yet been considered despite the fact that water volume exchange between the sea and the lagoon is supposed to be enhanced during spring tides, which could favors the entry of young fishes.

Therefore, the aim of this study was to evaluate the recruitment success of larval and juvenile fishes into a micro-tidal and shallow estuary related to the conjunction of global (lunar-tide cycle) and local (wind regime) processes. In order to do so, we explored spatial and temporal patterns in larval and juvenile fishes abundance related to neap/spring tides, winds and also water properties (temperature, salinity and transparency) that may vary according to tidal cycles (e.g. Primo et al. 2012). We hypothesize that the abundance of young fishes is higher during spring tides combined with strong onshore winds.

\section{Materials and methods}

\section{Study area}

The study area includes the Surf zone adjacent to Mar Chiquita lagoon's mouth and the lagoon's inlet channel (hereafter Estuary zone) (Fig. 1). See Merlotto and Bértola (2009) and González-Castro et al. (2009) for a more detailed description of the surf zone and Mar Chiquita's inlet channel, respectively.

\section{Biological and environmental sampling}

We focus on the spring-summer period because youngof-the-year (YOY) fishes were reported to be more abundant at these seasons in the marine-estuarine gradient of Mar Chiquita lagoon (Bruno 2014; Bruno et al. 2014) as well as in several temperate estuaries (e.g. Blaber and Blaber 1980; Potter et al. 1990; Martino and Able 2003). Fishes were collected weekly from October 2010 to March 2011, covering two spring tides (new moon and full moon) and two neap tides (waning and waxing) per month according 
Fig. 1 Map of Mar Chiquita lagoon and the location of the study area a), and distribution of the sampling stations in the surf zone (S1 and S2) and the inlet channel (E1 and E2) b)
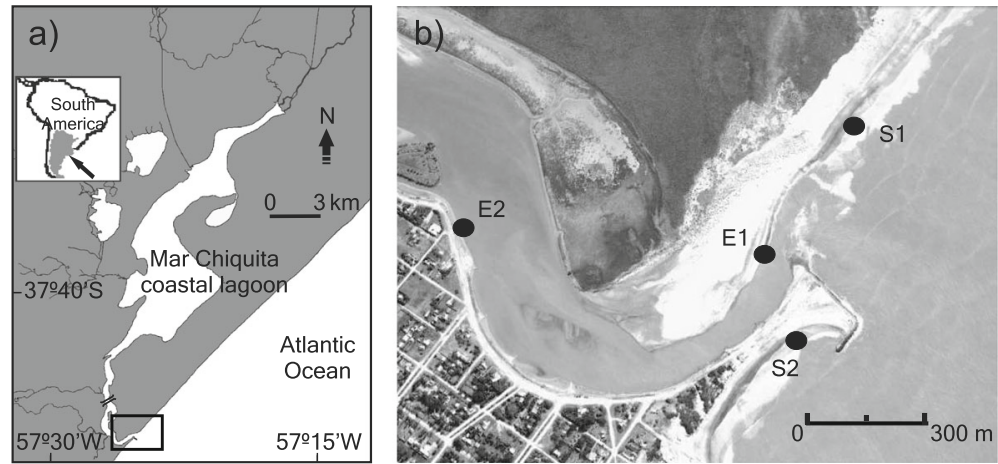

to the phase of the moon. Samples were taken at four stations covering the marine-estuarine gradient, including two stations in the Surf zone adjacent to the lagoon's mouth (S1 and S2) and two stations in the Estuary (E1 and E2) (Fig. 1).

Sampling was performed during daytime using a conical net with a $0.15 \mathrm{~m}^{2}$ mouth area and a $300 \mu \mathrm{m}$ mesh span net to collect larval stages, and a $4 \mathrm{~m}$ long, $1 \mathrm{~m}$ height nylon beach seine-net with a $5 \mathrm{~mm}$ stretch mesh size and a $2 \mathrm{~m}$ cod-end, to collect juvenile stages. Both nets were pulled against the prevailing current for $100 \mathrm{~m}$ parallel to shoreline at $\sim 1 \mathrm{~m}$ depth. The volume filtered by the conical net was almost $16 \mathrm{~m}^{3}$, while the area covered by the beach seine net was almost $400 \mathrm{~m}^{2}$. In order to assess for the neap/spring effects, samples were taken at flood tide in all stations. Fishes were fixed and preserved in $4 \%$ buffered formalinseawater solution, and transported to the laboratory for identification, sorting, counting and measuring [total length (TL in $\mathrm{mm}$ )].

Water temperature $\left({ }^{\circ} \mathrm{C}\right)$, salinity (psu) and transparency $(\mathrm{cm})$ were recorded with a hand thermometer, a Hydrobios refractometer and Secchi disc, respectively. Average wind speed and mode wind direction during the sampling day plus the 5 previous days were estimated for statistical analysis. In order to evaluate the wind effect, wind direction and speed was combined and turned into a four levels categorical variable accordingly to results obtained by Reta et al. (2001). Winds from S, $\mathrm{SE}$ and E were classified as "onshore wind" while winds from N, NW and W were classified as "offshore winds". Although SW and NE winds blow parallel to shoreline, their effect on the water level oscillations within the lagoon is evident (Reta et al. 2001). SW winds prevent the discharge of the lagoon, enhancing saltwater intrusion and, hence, increasing its water level.
Conversely, NE winds push the water from the lagoon towards the inlet channel, restricting sea water intrusion and favoring a decrease in the lagoon's water level (Reta et al. 2001). Therefore, SW and NE winds were classified as "onshore wind" and "offshore wind", respectively. Wind intensity was considered as strong $\left(>10 \mathrm{~m} \cdot \mathrm{s}^{-1}\right)$ and low-mid $\left(\leq 10 \mathrm{~m} \cdot \mathrm{s}^{-1}\right)$ accordingly to results obtained by Reta et al. (2001). Wind data was provided by the National Weather Service (Servicio Meteorológico Nacional, Argentina).

\section{Data analysis}

For statistical comparisons data were grouped into Spring (October, November and December) and into Summer (January, February and March).

Differences in water properties (temperature, salinity and transparency) between tides (neap, spring) by seasonzone interactions were evaluated with a Kruskal-Wallis test, followed by pair-wise comparisons using the SteelDwass-Critchlow-Fligner (SDCF) test under Addin-soft XLSTAT.

To test the hypothesis that the abundance of young fishes is higher during spring tides combined with strong onshore winds, a multiple-hypothesis model approach was adopted (Franklin et al. 2001; Johnson and Omland 2004). For each fish developmental stage (i.e. larval and juvenile), generalized linear models (GLM: Venables and Ripley 2002) (Package MASS, R Development Core Team 2012) were built with the number of fish captured as the response variable and the tidal stage (neap, spring) and the wind direction (Onshore, Offshore) combined with the wind speed $\left(\leq 10 \mathrm{~m} \cdot \mathrm{s}^{-1},>10 \mathrm{~m} \cdot \mathrm{s}^{-1}\right)$ as explanatory variables. The season (Spring, Summer), sites (S1, S2, E1, E2) and water parameters (temperature, salinity, 
transparency) were also considered as possible explanatory variables and, therefore, models with possible combinations of the above indicated environmental factors were also fitted (Table 1). Finally, a model without any of the independent variables (i.e. null model) was built to test the hypothesis that none of the variables tested had an effect on the fish abundance (Table 1). Since models had large variance-mean relationships and many zero values characterized the samples, a negative binomial error distribution and a log link were specified (Crawley 2005).

The Bayesian information criterion (BIC) (Package bbmle, R Development Core Team 2012), which is an approximation of the Bayes factor given no informative prior information on relative model support (Burnham and Anderson 2002, 2004; Ward 2008), was used for model comparisons and the model with the lowest BIC was selected as the best (Table 1). Each model was weighed against the others using Bayesian weights $(\varpi)$, which gives an estimation of the likelihood of the model's fit according to the data used (Burnham and Anderson 2002, 2004).

\section{Results}

Physical environment

Water temperature was only different between seasons (Table 2), with lower values recorded at Spring (Median: 16 , range: $10.3-22{ }^{\circ} \mathrm{C}$ ) than at Summer (Median: 21, range: $17-26^{\circ} \mathrm{C}$ ) (Fig. 2a). On the other hand, only spatial differences were observed in water salinity (Table 2) with lower values recorded at the Estuary zone (Median: 30, range: 20-35) than at the Surf zone (Median: 33, range: 26-35) (Fig. 2b). No differences were observed between tidal stage, seasons or zones on water transparency (Table 2), though it was observed a trend to lower values in the Surf zone than in the Estuary zone (Fig. 2c).

Low-mid $\left(\leq 10 \mathrm{~m} \cdot \mathrm{s}^{-1}\right)$ easterly winds were dominant during October [Frequency $(\mathrm{F})=16.13 \%$, Fig. 3a] and December ( $F=12.9 \%$, Fig. 3c), while southerly winds were dominant during November $(F=26.7 \%$, Fig. $3 b)$. Strong $\left(>10 \mathrm{~m} \cdot \mathrm{s}^{-1}\right)$ winds on the other hand, were dominant during Summer $(F>17 \%$, Fig. 3d-f).

Table 1 Competing models for explaining the recruitment of larval and juvenile fishes to Mar Chiquita choked lagoon

\begin{tabular}{|c|c|c|c|c|c|c|c|c|}
\hline \multirow[b]{2}{*}{ Model } & \multicolumn{4}{|l|}{ Larvae } & \multicolumn{4}{|c|}{ Juveniles } \\
\hline & $\mathrm{BIC}$ & $\mathrm{df}$ & $\mathrm{dBIC}$ & & $\mathrm{BIC}$ & $\mathrm{df}$ & $\mathrm{dBIC}$ & \\
\hline Null & 320.3 & 2 & 4.9 & 0.0451 & 1023.3 & 2 & 11 & 0.0026 \\
\hline$\sim$ season & 318.1 & 3 & 2.7 & 0.1324 & 1016.4 & 3 & 4.2 & 0.0794 \\
\hline$\sim$ site & 332.3 & 5 & 16.9 & $<0.001$ & 1022.6 & 5 & 10.4 & 0.0036 \\
\hline tide & 324.8 & 3 & 9.4 & 0.0046 & 1027.7 & 3 & 15.5 & $<0.001$ \\
\hline$\sim$ wind & 319.6 & 5 & 4.1 & 0.0652 & 1019.6 & 5 & 7.4 & 0.0163 \\
\hline$\sim$ temperature (temp) & 321.3 & 3 & 5.9 & 0.0274 & 1026.7 & 3 & 14.5 & $<0.001$ \\
\hline$\sim$ salinity (sal) & 320.4 & 3 & 5 & 0.0424 & 1027.4 & 3 & 15.2 & $<0.001$ \\
\hline$\sim \operatorname{transparency~(trans)}$ & 319.2 & 3 & 3.7 & 0.0794 & 1030.1 & 3 & 17.9 & $<0.001$ \\
\hline$\sim$ temp + sal + trans & 320.2 & 5 & 4.7 & 0.0483 & 1031.2 & 5 & 19 & $<0.001$ \\
\hline$\sim$ season + site & 324.3 & 6 & 8.9 & 0.0061 & 1014.2 & 6 & 1.9 & 0.2477 \\
\hline$\sim$ season+tide & 321.1 & 4 & 5.6 & 0.0308 & 1023.8 & 4 & 11.6 & 0.0019 \\
\hline$\sim$ season+wind & 315.4 & 6 & $\mathbf{0}$ & 0.5146 & 1012.2 & 6 & $\mathbf{0}$ & 0.6463 \\
\hline$\sim$ site+tide & 336.4 & 6 & 21 & $<0.001$ & 1026.4 & 6 & 14.1 & $<0.001$ \\
\hline$\sim$ site+wind & 332.3 & 8 & 16.9 & $<0.001$ & 1030.3 & 8 & 18.1 & $<0.001$ \\
\hline$\sim$ tide + wind & 325.5 & 6 & 10.1 & 0.0033 & 1035.7 & 6 & 23.5 & $<0.001$ \\
\hline$\sim$ season + site + tide + wind & 333.8 & 10 & 18.4 & $<0.001$ & 1027.6 & 10 & 15.4 & $<0.001$ \\
\hline$\sim$ season + site + tide + wind + temp + sal + trans & 340.5 & 13 & 25.1 & $<0.001$ & 1032.1 & 13 & 19.9 & $<0.001$ \\
\hline
\end{tabular}

For each model, Bayesian Information Criterion (BIC), degrees of freedom (df), the difference between BIC of the current model and the most parsimonious model (in bold) (dBIC), and the Bayesian weight $(\varpi)$ are given 
Table 2 Kruskal-Wallis rank sum test results and posteriori Steel-Dwass-Critchlow-Fligner (SDCF) pair-wise comparisons for water parameters recorded between spring and neap tides by seasons and zones along the Mar Chiquita's inlet and its adjacent surf zone
Kruskal-Wallis rank sum test
SDCF-test

\begin{tabular}{lllll}
\cline { 2 - 4 } Source & $\chi^{2}$ & df & $p$-value & \\
\hline Temperature & 29.815 & 7 & 0.0001 & $\mathrm{~A}=\mathrm{B}=\mathrm{C}=\mathrm{D}<\mathrm{E}=\mathrm{F}=\mathrm{G}=\mathrm{H}$ \\
Salinity & 14.861 & 7 & 0.0378 & $\mathrm{~A}=\mathrm{B}=\mathrm{E}=\mathrm{F}>\mathrm{C}=\mathrm{D}=\mathrm{G}=\mathrm{H}$ \\
Transparency & 9.745 & 7 & 0.2035 & - \\
\hline
\end{tabular}

Spring-Surf zone-neap (A), Spring-Surf zone-spring (B), Spring-Estuary-neap (C), Spring-Estuary-spring (D), Summer-Surf zone-neap (E), Summer-Surf zone-spring (F), Summer-Estuary-neap (G), Summer-Estuary-spring $(H)$

Composition and abundance of YOY fishes and their relationship with the environment

A total of 19 taxa were collected during the study period; five of those taxa were represented by both larval and juvenile stages (Table 3). Engraulid type larvae cannot be identified into species, so the category Engraulidae family includes unidentified individuals of likely Anchoa marinii, E. anchoita and/or Lycengraulis grossidens (Table 3).

Fish larvae abundance along the marine-estuarine gradient of Mar Chiquita was mainly affected by wind regimen and seasonal changes according to the model used (Table 1). High abundance of fish larvae in Mar Chiquita's inlet channel and its surrounding surf zone were collected in summer (Table 4, Fig. 4a). Nevertheless, in all seasons sampled, high larval abundance was related to onshore winds (SO, S, SE, E) and particularly to strong (>10 m $\cdot \mathrm{s}^{-1}$ ) winds (Fig. 4a). Similarly, the abundance of juvenile fishes was mainly affected by wind regimen and seasonal changes (Table 1). For this developmental stage, high abundance was collected in summer (Table 4, Fig. 4b). Also, high abundance of juvenile fishes was related to strong onshore winds (Table 4, Fig. 4b).

\section{Discussion}

Variations in water parameters

According to our results, variations in temperature and salinity of the inlet area of the Mar Chiquita lagoon, including the adjacent surf zone, were not related to lunar-tide cycles. The observed variations depend, instead, on other factors such as seasonality in the case of temperature or to an upstream freshwater input that generates a horizontal gradient (low to high towards the inlet) in the case of salinity, which were previously reported (Cousseau et al. 2001; González-Castro et al.
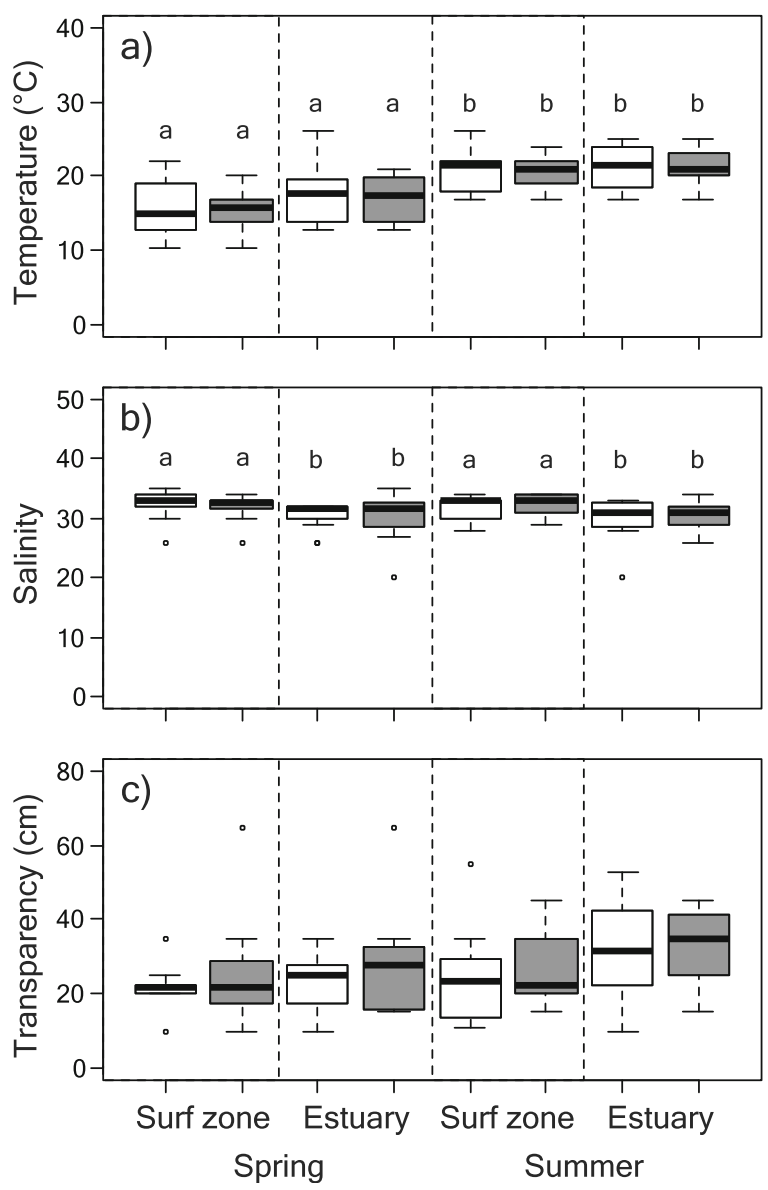

Fig. 2 Seasonal and spatial variation in water temperature a), salinity b) and transparency c) between neap (white boxes) and spring (gray boxes) tides (line: median; box: 25 th to 75 th percentiles; whiskers: minimum to maximum value range). Different letters denote significant differences. Filled circles represent outliers 


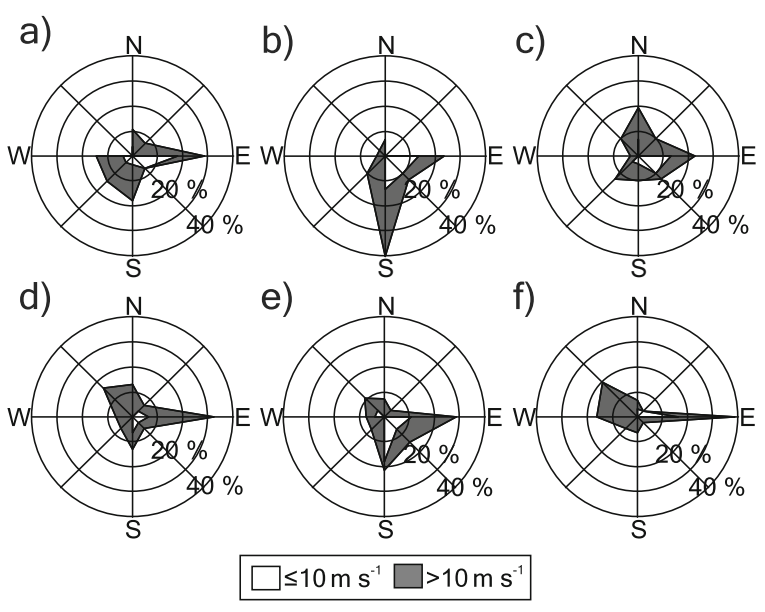

Fig. 3 Temporal variation of wind direction and speed during spring months: a) October 2010, b) November 2010, c) December 2010, and during summer months: d) January 2011, e) February 2011, f), March 2011
Table 4 The best minimum model used to explain the recruitment of fish larvae and juveniles to Mar Chiquita's inlet and its adjacent surf zone

\begin{tabular}{llrr}
\hline Variable & Class variable & \multicolumn{2}{l}{ Coefficient $\pm \mathrm{SD}$} \\
\cline { 3 - 4 } & & \multicolumn{1}{l}{ Fish larvae } & Fish juveniles \\
\hline Intercept & & $-0.875 \pm 0.618$ & $1.065 \pm 0.371$ \\
$S_{i}$ & Summer & $1.031 \pm 0.412$ & $3.642 \pm 0.458$ \\
$W_{i}$ & Offshore $>10 \mathrm{~m} \mathrm{~s}^{-1}$ & $-0.009 \pm 0.818$ & $-0.005 \pm 0.651$ \\
& Onshore $\leq 10 \mathrm{~m} \mathrm{~s}^{-1}$ & $0.361 \pm 0.722$ & $0.433 \pm 0.585$ \\
& Onshore $>10 \mathrm{~m} \mathrm{~s}^{-1}$ & $1.274 \pm 0.732$ & $0.730 \pm 0.554$
\end{tabular}

The intercept and coefficient \pm standard error (SD) for the variables are given. $S_{i}$ : season; $W_{i}$ : wind direction (Onshore: SW, S, SE, E; Offshore: NE, N, NW, W) combined with wind speed $\left(\leq 10 \mathrm{~m} \cdot \mathrm{s}^{-1},>10 \mathrm{~m} \cdot \mathrm{s}^{-1}\right)$. The parameters for season and wind effect are given as relative to spring and offshore $\leq 10 \mathrm{~m} \cdot \mathrm{s}^{-1}$, respectively

Table 3 Seasonal abundance $(\mathrm{N})$ and total length $(\mathrm{TL}, \mathrm{mm})$ range of fish larvae collected with a conical net and fish juveniles collected with a beach-seine net along Mar Chiquita's inlet and its adjacent surf zone

\begin{tabular}{|c|c|c|c|c|c|c|c|c|c|c|c|c|}
\hline & \multicolumn{6}{|c|}{ Spring } & \multicolumn{6}{|c|}{ Summer } \\
\hline & \multicolumn{4}{|c|}{ Larvae } & \multicolumn{2}{|c|}{ Juveniles } & \multicolumn{4}{|c|}{ Larvae } & \multicolumn{2}{|c|}{ Juveniles } \\
\hline & $\mathrm{N}$ & $\operatorname{PrF}$ & PoF & $\mathrm{TL}$ & $\mathrm{N}$ & $\mathrm{TL}$ & $\mathrm{N}$ & $\operatorname{PrF}$ & PoF & $\mathrm{TL}$ & $\mathrm{N}$ & $\mathrm{TL}$ \\
\hline Brevoortia aurea & 6 & 29.4 & 70.6 & $1.92-20.04$ & 82 & $28-87$ & 59 & - & 100 & $7.51-29$ & 8321 & $20-87$ \\
\hline Cynoscion guatucupa & - & - & - & - & - & - & 1 & - & 100 & 30 & - & - \\
\hline Engraulidae & 2 & 100 & - & $2.64-3.06$ & - & - & 9 & - & 100 & $15.86-35$ & - & - \\
\hline Gobiosoma parri & 3 & 100 & - & $6.35-6.38$ & - & - & 27 & 100 & - & $1.86-2.79$ & - & - \\
\hline Hypleurochilus fissicornis & - & - & - & - & - & - & 7 & 100 & - & $1.68-2.16$ & - & - \\
\hline Lycengraulis grossidens & - & - & - & - & - & - & - & - & - & - & 123 & $23-126$ \\
\hline Macrodon atricauda & - & - & - & - & - & - & - & - & - & - & 1 & 34 \\
\hline Menticirrhus americanus & - & - & - & - & - & - & - & - & - & - & 8 & $47-118$ \\
\hline Micropogonias furnieri & - & - & - & - & 3 & $54-143$ & 3 & - & 100 & $17-24.5$ & 228 & $23-119$ \\
\hline Mugil liza & - & - & - & - & 1 & 27 & & - & - & - & 447 & $22-60$ \\
\hline Odontesthes argentinensis & 26 & - & 100 & $18.34-31$ & 514 & $25-133$ & 9 & 16.67 & 83.33 & $8.02-32$ & 2364 & $25-160$ \\
\hline Oncopterus darwinii & - & - & - & - & - & - & - & - & - & - & 10 & $28-70$ \\
\hline Paralichthys orbignyanus & - & - & - & - & 2 & $94-171$ & 3 & - & 100 & $8.68-9.18$ & 9 & $135-179$ \\
\hline Platanichthys platana & - & - & - & - & 52 & $24-58$ & - & - & - & - & - & - \\
\hline Pogonias cromis & - & - & - & - & - & - & - & - & - & - & 1 & 95 \\
\hline Pomatomus saltatrix & - & - & - & - & - & - & - & - & - & - & 1 & 126 \\
\hline Ramnogaster arcuata & - & - & - & - & 20 & $60-85$ & - & - & - & - & 18 & $52-67$ \\
\hline Umbrina canosai & - & - & - & - & - & - & 1 & - & 100 & 16.2 & - & - \\
\hline Unidentified & - & - & - & - & - & - & 1 & 100 & - & 2.13 & - & - \\
\hline
\end{tabular}

For fish larvae, the percentage (\%) of developmental stage (PrF: preflexion, PoF: postflexion) is also indicated 

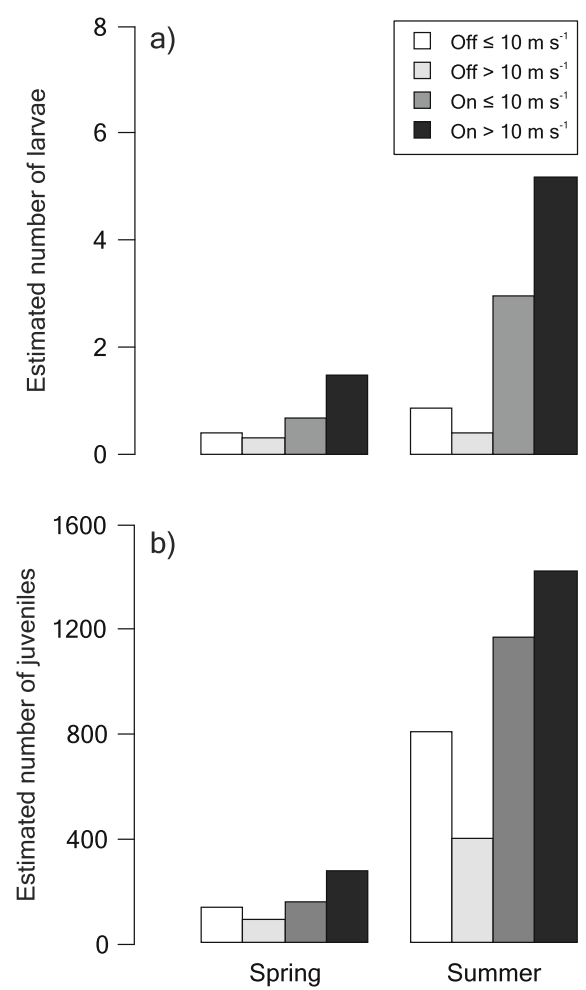

Fig. 4 Estimated abundance of fish larvae a) and juveniles b) related to seasons and wind direction (Off: Offshore, On: Onshore) and intensity along Mar Chiquita's inlet and its adjacent surf zone, estimated by a generalized linear models with a log link and negative binomial error distribution

2009). A trend of high to low values in water transparency towards the surf zones was observed which has been previously attributed to the turbulence generated by wave action (Bruno et al. 2014). However, transparency differences were not significant between tides, as well as between season and between zones. Variations in water salinity and transparency related to lunar-tide cycles in estuarine environments have been attributed to a greater and lesser volume of seawater entering during floods in spring and neap tides, respectively (Kjerfve and Magill 1989). Such variations have also been attributed to the combination of the variability in seawater volume entrance according to lunar-tide cycles with the seasonal variation in river flows due to seasonality in rainfall (e.g. Primo et al. 2012). The scarce variation in water parameters (temperature, salinity and transparency) between spring and neap tides in Mar Chiquita may be due to the combination of the shallowness of the system (1.5-3 m) with the major contribution of seawater input compared to the freshwater contribution (a single stream discharges into the inlet channel,
Reta et al. 2001). This combination generates a system with permanent mixing of water with no stratification patterns (Kjerfve and Magill 1989).

Variations in YOY fishes related to the environment

The results obtained during this study show that high abundances of larval and juvenile fishes are not related to the combination of lunar-tide cycles with the wind direction and intensity, thus rejecting our hypothesis, but to the combination of the wind direction and speed with the seasons.

Entering of late larvae (post flexion) and early juvenile fishes into temperate estuaries in greater abundance during the summer months is the most commonly recruitment pattern for those species which reproduce in sea waters within late spring/early summer (Potter et al. 2001). Previous studies conducted in Mar Chiquita have shown that most of fish species of marine origin present in Mar Chiquita as larvae (Bruno et al. 2014) and juveniles (Bruno 2014) fit to the "estuarine-opportunistic" guild sensu Blaber et al. (1989) and Lenanton and Potter (1987) [excepting for the estuarine resident G. parri (Cousseau et al. 2001) and the marine straggler H. fissicornis (Delpiani et al. 2012)] and that are more abundant in summer than in spring. The use of Mar Chiquita lagoon as nursery ground for juvenile fishes has been largely recognized (Cousseau et al. 2001; Martinetto et al. 2007; González-Castro et al. 2009). However, the presence of fish larvae indicates that this estuarine system presents proper condition for retention of these tiny stages. Therefore, the fact that some species are present in both stages (e.g. Brevoortia aurea, Micropogonias furnieri, Odontesthes argentinensis, Paralichthys orbignyanus) while some others are present only in juvenile stages (Menticirrhus americanus, Oncopterus darwinii, Platanichthys platana, Ramnogaster arcuata) may be related to differences in the distance of the nursery ground (Mar Chiquita in this case) from the reproductive area (Jones 2002).

Regardless of the period (spring or summer) in which fishes recruit to this estuarine system, wind direction is significant for the success of such entry according to our results (Table 4; Fig. 4a and b). The distribution of fishes within Mar Chiquita lagoon related to the wind effect has been previously mentioned, mainly for explaining the occasional presence of tropical and subtropical marine teleost fishes due to the incursion of warm neritic waters to the Argentine continental shelf in combination 
with winds from the oceanic region (e.g. Díaz de Astarloa et al. 2000; Figueroa et al. 2000; GonzálezCastro et al. 2006; Blasina et al. 2009; Bruno et al. 2011). Also, a restriction in the distribution of freshwater fishes from the tributary streams to the lagoon has been related to the wind regimen (Bruno et al. (2013). Reta et al. (2001) stated that strong onshore winds $\left(>10 \mathrm{~m} \cdot \mathrm{s}^{-1}\right)$ sustained over time are more significant than tidal cycles in the penetration of water into inner areas of the Mar Chiquita lagoon, mainly due to the shallowness $(1.5-3 \mathrm{~m})$ of the inlet channel area and to the micro-tidal characteristic of the region. They also suggested that in the opposite situation (very low winds or calms) tidal cycles should regulate the oscillation of the water level at the mouth of Mar Chiquita. However, such a condition should not be a typical one in the area since, according to our results, the wind effect was more significant in the recruitment of fishes than tidal stage even under low-mid $\left(\leq 10 \mathrm{~m} \cdot \mathrm{s}^{-1}\right)$ winds (Fig. 4). Nevertheless, it could be assumed that when offshore winds are dominant, the entry of YOY fishes is lower during strong $\left(>10 \mathrm{~m} \cdot \mathrm{s}^{-1}\right)$ episodes than during lowmid $\left(\leq 10 \mathrm{~m} \cdot \mathrm{s}^{-1}\right)$ ones, due to a lesser marine water income into the lagoon; it could be argued then that in very shallow estuarine systems (like Mar Chiquita) water movement in and out are regulated by local factors such as the prevailing winds, and not by large-scale factors such as tidal cycles.

There is, however, certain regularity in the wind regime depending on the seasons. In Mar Chiquita lagoon area, winds from North, South and East are dominant during the summer months (Reta et al. 2001), being beneficial for the recruitment of fish early life stages those from South and East (i.e. onshore winds). During this study, easterly winds were dominant in almost every month, being more frequent and intense in summer (Fig. 3), in agreement with results obtained for the same season in previous years (Bruno 2014; Bruno et al. 2014). This seasonal regularity appears to be beneficial for those fish species that spawn in marine waters near the mouth of the lagoon, given that onshore winds that carry seawater towards the coast, and increase the water level of Mar Chiquita lagoon, are dominant in the summer period where peak abundances of larval and juvenile fishes are observed.

Several studies have shown variations in the composition of fish larvae related to the different phases of the lunar-tide cycle (neap and spring) in estuaries deep enough as to allow for stratification of the water column (e.g., Schultz et al. 2003; Primo et al. 2012). Mainly, it has been established that the strong currents and large volumes of water moving during spring tides could passively transport fish larvae into intertidal areas (Hampel et al. 2003). Furthermore, it has also been reported variations in juvenile fish distribution in shallow estuarine systems related to the spring and neap tides (Kneib and Wagner 1994; Rozas 1995; Morrison et al. 2002; Greenwood and Hill 2003). Such variations were attributed to the movement of fishes into productive intertidal zones, which are only available during certain periods of flooding depending on the lunar-tide cycle. Despite their seasonal regularity, wind is a much more unpredictable factor than the tides. For instance, in those estuarine systems where water movements are ruled by the effect of the tidal cycle, fishes take advantage of the different phases of these cycles to entry and/ or stay in them (Weinstein et al. 1980; Boehlert and Mundy 1988; Forward et al. 1999; Primo et al. 2012). Also, this advantage has been related to length classes by assessing at which size fishes enter into an estuary (e.g., Cowley et al. 2001). Therefore, it is remarkable to note the implications that have for fishes the recruitment towards an estuarine system depending on an unpredictable forcing (i.e. wind) over other cases where recruitment depends on regular and predictable processes such as tides.

It has been proposed that the marine area adjacent to Mar Chiquita's inlet functions as an accumulation zone for larval (Bruno et al. 2014) and juvenile (Bruno 2014) stages prior to entering the lagoon, like it has been proposed for other estuaries (Boehlert and Mundy 1988). Moreover, the marine area could also serve as nursery ground for both stages given the significance of the wind effect over the daily-tide cycle in the recruitment of fishes. Thus, fishes that do not find appropriate conditions to enter at this shallow estuarine system, with increased supply of food compared to the adjacent sea (Marcovecchio et al. 2006), may remain in that sea area until appropriate conditions occur to enter, or not (Bruno 2014). Results obtained during this study support such proposal given that higher abundances of larval and juvenile fishes were related to winds rather than to spring/neap tides, suggesting that the effect of wind prevailed even over the broader lunar-tidal scale in the recruitment of fishes. Therefore, if fishes are in the accumulation sea area, strong onshore winds will allow the entrance of YOY fishes into Mar Chiquita by pushing seawater into inner areas of the estuary. Conversely, 
strong offshore winds restrict the entry of sea water into the lagoon and consequently, also the fish entrance. In turn, these offshore winds may also favor the water discharge from the lagoon to the sea, inducing the export of small stages with low motility, which have been entered in Mar Chiquita's inlet. In this scenario, a coastal area close to the mouth of an estuary that also functions as nursery ground would be beneficial to minimize mortality by dispersion as stated by Houde (2002).

Acknowledgments We express our gratitude to Buenos Aires Province Ministry of Agrarian Subjects' authorities, M. Iza and J. Mangiarotti (forest guard of Mar Chiquita Biosphere Reserve) for sampling permission; to S.M. Delpiani, G.E. Blasina, L.B. Sansosti, R.D. Becerra, H.P. Lértora, D. Rodríguez-Golpe, M.Y. Deli-Antoni and F. Sala, for field assistance; and to A.T. Gómez (National Weather Service, Argentina) who kindly provided rainfall and wind data. We also acknowledge S.A. Barbini, M.B. Cousseau and anonymous reviewers for useful comments on an early draft. D.O.B. was supported by fellowships from CONICET (Argentina). This is part of D.O.B's Ph.D. thesis.

\section{References}

Blaber SJM, Blaber TG (1980) Factors affecting the distribution of juvenile estuarine and inshore fish. J Fish Biol 17:143-162

Blaber SJM, Brewer DT, Salini JP (1989) Species composition and biomasses of fishes in different habitats of a tropical Northern Australian estuary: their occurrence in the adjoining sea and estuarine dependence. Estuar Coast Shelf Sci 29: 509-531

Blasina GE, Delpiani SM, Bruno DO, González-Castro M, Díaz de Astarloa JM (2009) First record of Callorhinchus callorynchus and Trachurus lathami, in a south-western Atlantic coastal lagoon. Mar Biodivers Rec 2(e90):1-3

Boehlert GW, Mundy BC (1988) Roles of behavioral and physical factors in larval and juvenile fish recruitment to estuarine nursery areas. Am Fish Soc Symp 3:51-67

Bruno DO (2014) Patrones de utilización de la laguna Mar Chiquita (Buenos Aires, Argentina) y área costera adyacente por parte de los primeros estadios ontogénicos de peces. Universidad Nacional de Mar del Plata

Bruno DO, Addino M, Díaz de Astarloa JM (2011) Southernmost occurrence of Syngnathus folletti on a temperate coastal lagoon of Argentina. Mar Biodivers Rec 4(e62):1-3

Bruno DO, Barbini SA, Díaz de Astarloa JM, Martos P (2013) Fish abundance and distribution patterns related to environmental factors in a choked temperate coastal lagoon (Argentina). Braz J Oceanogr 61:43-53

Bruno DO, Delpiani SM, Cousseau MB, de Astarloa JM D, Blasina GE, Mabragaña E, Acha EM (2014) Ocean-estuarine connection for ichthyoplankton through the inlet channel of a temperate choked coastal lagoon (Argentina). Mar Freshw Res 65(12):1116-1130
Burnham KP, Anderson DR (2002) Model selection and multimodel inference: a practical information theoretic approach. Springer, New York

Burnham KP, Anderson DR (2004) Multimodel inference: understanding AIC and BIC in model selection. Sociol Methods Res 33:261-304

Cousseau MB, Díaz de Astarloa JM, Figueroa DE (2001) La Ictiofauna de la Laguna Mar Chiquita. In: Iribarne O (ed) Reserva de Biósfera Mar Chiquita: Características físicas, biológicas y ecológicas. Editorial Martín, Mar del Plata, pp 187-203

Cowley PD, Whitfield AK, Bell KNI (2001) The surf zone ichthyoplankton adjacent to an intermittently open estuary, with evidence of recruitment during marine over wash events. Estuar Coast Shelf Sci 52:339-348

Crawley MJ (2005) Statistics: an introduction using R. Wiley, Chichester

Day JW Jr, Hall CAS, Kemp WM, Yáñez-Arancibia A (1989) Estuarine ecology. Wiley, New York

Delpiani SM, Bruno DO, Díaz de Astarloa JM, Acuña F (2012) Development of early life stages of the blenny Hypleurochilus fissicornis (Blenniidae). Cybium 36(2):357359

Díaz de Astarloa JM, Figueroa DE, Cousseau MB, Barragán M (2000) Occurrence of Trachinotus carolinus (Carangidae) in laguna costera Mar Chiquita, with comments on other occasionally recorded fishes in Argentinean waters. Bull Mar Sci 66:399-403

Epifanio CE, Garvine RW (2001) Larval transport on the Atlantic continental shelf of North America: a review. Estuar Coast Shelf Sci 52:51-77

Figueroa DE, Díaz de Astarloa JM, Cousseau MB (2000) Southernmost occurrence of the aguavina on the western Atlantic coast of Argentina. J Fish Biol 56:1280-1282

Forward RB Jr, Reinsel KA, Tankersley RA, Churchill JH, Crowder LB, Hettler WF, Warlen SM, Green MD (1999) Transport of fish larvae through a tidal inlet. Fish Oceanogr 8: 153-172

Franklin AB, Shenk TM, Anderson DR, Burnham KP (2001) Statistical model selection: An alternative to null hypothesis testing. In: Shenk TM, Franklin AB (eds) Modeling in natural resource management. Development, interpretation and application. Island Press, Washington DC, pp 75-90

González-Castro M, Díaz de Astarloa JM, Cousseau MB (2006) First record of a tropical affinity mullet, Mugil curema (Mugilidae), in a temperate southwestern Atlantic coastal lagoon. Cybium 30:90-91

González-Castro M, Díaz de Astarloa JM, Cousseau MB, Figueroa DE, Delpiani SM, Bruno DO, Guzonni JM, Blasina GE, Deli-Antoni MY (2009) Fish composition in a south-western Atlantic temperate coastal lagoon: spatial-temporal variation and relationships with environmental variables. J Mar Biol Assoc U K 89:593604

Greenwood MFD, Hill AS (2003) Temporal, spatial and tidal influences on benthic and demersal fish abundance in the Forth estuary. Estuar Coast Shelf Sci 58:211-225

Hampel H, Cattrijjse A, Vincx M (2003) Tidal, diel and semi-lunar changes in the faunal assemblage of an intertidal salt marsh creek. Estuar Coast Shelf Sci 56:795-805 
Houde ED (2002) Chapter 3: mortality. In: Fuiman LA, Werner RG (eds) Fishery science: the unique contributions of early life stages. Blackwell Science, Oxford, pp 64-87

Islam MS, Hibino M, Tanaka M (2007) Tidal and diurnal variations in larval fish abundance in an estuarine inlet in Ariake Bay, Japan: implication for selective tidal stream transport. Ecol Res 22:165-171

Jager Z (1999) Selective tidal stream transport of flounder larvae (Platichthys flesus L.) in the Dollard (Ems Estuary). Estuar Coast Shelf Sci 49:347-362

Johnson JB, Omland KS (2004) Model selection in ecology and evolution. Trends Ecol Evol 19:101-108

Jones CM (2002) Chapter 2: age and growth. In: Fuiman LA, Werner RG (eds) Fishery science: the unique contributions of early life stages. Blackwell Science, Oxford, pp 33-63

Kjerfve B (1994) Coastal lagoons. In: Kjerfve B (ed) Coastal lagoon processes. Elsevier Oceanography Series 60, Amsterdam, pp 1-8

Kjerfve B, Magill KE (1989) Geographic and hydrodynamic characteristics of shallow coastal lagoons. Mar Geol 88: 187-199

Kneib RT, Wagner SL (1994) Nekton use of vegetated marsh habitats at different stages of tidal inundation. Mar Ecol Prog Ser 106:227-238

Lenanton RCJ, Potter IC (1987) Contribution of estuaries to commercial fisheries in temperate Western Australia and the concept of estuarine dependence. Estuaries 10:28-35

Marcovecchio J, Freije H, De-Marco S, Gavio A, Ferrer L, Andrade S, Beltrame O, Asteasuain R (2006) Seasonality of hydrographic variables in a coastal lagoon: Mar Chiquita, Argentina. Aquatic Conserv Mar Freshw Ecosyst 16:335-347

Martinetto P, Ribeiro P, Iribarne O (2007) Changes in distribution and abundance of juvenile fishes in intertidal soft sediment areas dominated by the burrowing crab Chasmagnathus granulatus. Mar Freshw Res 58:194-203

Martino EJ, Able KW (2003) Fish assemblages across the marine to low salinity transition zone of a temperate estuary. Estuar Coast Shelf Sci 56:969-987

Martos P, Reta R, Guerrero RA (2004) El ambiente físico de las costas marplatenses: su clima y sus aguas. In: Boschi EE, Cousseau MB (eds) La vida entre mareas: vegetales y animales de las costas de Mar del Plata, Argentina. Publicaciones especiales INIDEP, Mar del Plata, pp 29-42
Merlotto A, Bértola G (2009) Coastline evolution at Balneario Parque Mar Chiquita, Argentina. Cienc Mar 35:271-286

Miller JM, Crowder LB, Moser ML (1985) Migration and utilization of estuarine nurseries by juvenile fishes an evolutionary perspective. Contrib Mar Sci 27:338-352

Morrison MA, Francis MP, Hartill BW, Parkinson DM (2002) Diurnal and tidal variation in the abundance of fish fauna of a temperate tidal mudflat. Estuar Coast Shelf Sci 54:793-807

Potter IC, Beckley LE, Whitfield AK, Lenanton RCJ (1990) Comparisons between the roles played by estuaries in the life cycles of fishes in temperate Western Australia and Southern Africa. Environ Biol Fish 28:143-178

Potter IC, Bird DJ, Claridge PN, Clarke KR, Hyndes GA, Newton LC (2001) Fish fauna of the Severn Estuary. Are there longterm changes in abundance and species composition and are the recruitment patterns of the main marine species correlated? J Exp Mar Biol Ecol 258:15-37

Primo AL, Azeiteiro UM, Marques SC, Ré P, Pardal MA (2012) Vertical patterns of ichthyoplankton at the interface between a temperate estuary and adjacent coastal waters: Seasonal relation to diel and tidal cycles. J Mar Syst 95:16-23

R Development Core Team (2012) R: a language and environment for statistical computing. R Foundation for Statistical Computing (Version 2.14.2). Available at http://www.Rproject.org/

Reta R, Martos P, Perillo GME, Piccolo MC, Ferrante A (2001) Características hidrográficas del estuario de la laguna Mar Chiquita. In: Iribarne O (ed) Reserva de Biósfera Mar Chiquita: Características físicas, biológicas y ecológicas. Editorial Martín, Mar del Plata, pp 31-52

Rozas LP (1995) Hydroperiod and its influence on nekton use of the salt marsh: a pulsing ecosystem. Estuaries 18:579-590

Schultz ET, Lwiza KMM, Fencil MC, Martin JM (2003) Mechanisms promoting upriver transport of larvae of two fish species in the Hudson River estuary. Mar Ecol Prog Ser 251:263-277

Venables WN, Ripley BD (2002) Modern applied statistics with SPlus. Springer, New York, p 584

Ward E (2008) A review and comparison of four commonly used Bayesian and maximum likelihood model selection tools. Ecol Model 211:1-10

Weinstein MP, Weiss SL, Hodson RG, Gerry LR (1980) Retention of three taxa of postlarval fishes in an intensively flushed tidal estuary, Cape Fear River, North Carolina. Fish Bull 78:419-436 